immense value. Both Governments are agreed that this important defence project should continue to be treated as a joint enterprise.

\section{Use of Atomic Energy in Britain for Electrical Power}

IN a debate in the House of Commons on the fuel and power industries, held on October 26, the Minister of Fuel and Power, Mr. Geoffrey Lloyd, indicated that we are likely to get useful quantities of electricity from the new nuclear establishment at Calder Hall in Cumberland, and also from the new breeder reactor. It is expected that about 50,000 $\mathrm{kW}$. would be generated as the result of these nuclear activities, and they would provide the data on which future atomic generating stations would be based. Mr. Lloyd stated that there is no reason why atomic power stations should not before long make a useful addition to power resources in Britain. In reply to a further question to the Minister of Supply on October 27 , regarding scientific advances during the past two years in using nuclear energy for industrial, domestic, transport and other peaceful purposes, Mr. A. R. W. Low, Parliamentary Secretary to the Ministry of Supply, stated that design studies on a nuclearpower station, using natural uranium as a fuel, have been completed, and an experimental power station of this type is being constructed at Calder Hall. A low-power breeder reactor is nearing completion at Harwell. Design studies are being carried out on a higher-powered reactor of this type, and. are also proceeding on other types of reactors which might be suitable for development of power. The application of radioactive isotopes to industrial, medical and research purposes continues to extend, and plans are being made to increase the facilities for their production.

\section{Pest Infestation Laboratory: New Biochemistry Building}

A NEw building for biochemical research at the Pest Infestation Laboratory, Department of Scientific and Industrial Research, Slough, Bucks, was opened by Sir Ben Lockspeiser, in the presence of Mr. G. V. B. Herford (director of the Laboratory) and members of the Pest Infestation Research Board, on November 6. Biochemistry at this Laboratory includes studies on mechanisms of insecticidal action, and on the contamination of stored food products by insecticides and fumigants. Much of the work has been characterized by the extensive use and development of radioactive tracer techniques. The building is of singlestory construction and consists of ten laboratories, cloak rooms and boiler room. Two principal end laboratories provide for 'semi-hot' radiochemical and radiobiological work. Each of these contains a threeunit high-efficiency fume chamber provided with stainless steel tray working areas. Other features include two insulated temperature-controlled rooms ventilated with dust-free air for radiometric and enzyme assay respectively. Service points are mounted clear of all working bench surfaces, and have front bench panel controls. Sink wastes run directly to two external drains provided with inspection covers throughout their lengths and a delay tank for monitoring and decontamination. Mr. F. P. W. Winteringham (officer-in-charge of biochemistry in the Laboratory) was responsible for the basic layout of laboratories and services. Throughout planning and construction there was a close and successful co-operation between the scientific per- sonnel and Ministry of Works architects concerned (Messrs. R. J. Sneller and A. F. J. Hannaford).

\section{Anglo-Italian Mixed Commission}

The Anglo-Italian Mixed Commission of ten members established under Article XII of the Cultural Convention, recently ratified by the British and Italian Parliaments, held its first series of meetings in London from October 26 onwards, under the chairmanship of Sir Ronald Adam. The other members of the British section were Prof. E. R. P. Vincent, professor of Italian in the Univer. sity of Cambridge; Prof. J. Read, professor of chemistry in the University of St. Andrews ; Mr. D. C. Riddy, Ministry of Education ; and Mr. K. R. Johnstone, British Council. Lord Crawford and Balcarres, who is also a member of the Commission, was unable to be present. The Italian section was led by Signor Bartolomeo Migone, director-general of cultural relations in the Italian Ministry of Foreign Affairs. Cultural relations between Italy and Britain were firmly established before the signing of the Cultural Convention, the declared object of which is to give the fullest possible support to exchanges covering the intellectual, artistic, scientific, technical and educational activities of each country. At its first series of meetings in London, the Commission reviewed the terms of the Convention in detail and examined projects for future development. The next series of meetings of the full Mixed Commission will be held in Rome. The British Council is designated by the British Government as their principal agent for the execution of the measures falling within the scope of the Convention.

\section{Reclamation of Deserts}

A RECENT issue of Trees $(17$, No. 2 ; 1953) includes several articles on the important question of the spread of aridity, notably in the tropical and subtropical regions, with accounts of current work for its prevention or reduction and the reclamation of affected areas in the U.S.S.R., China and elsewhere. Under the title of "The Recovery of the Sahara", R. St. Barbe Baker refers to his personal experiences of the problems involved and the part he would like to see taken by the society he started some years ago under the name "The Men of the Trees". While some of the proposals, such as "carrying out surveys, studies and pilot schemes", and "fostering a centre for education and research in the forestry aspects of reclaiming the bad lands", are far beyond the capacity of the society, if indeed appropriate to it, any constructive action helping to direct public attention to the urgent need for realization of the dangers of the situation and to stimulate appropriate action is worthy of support. It is, however, important to avoid representing as proved, or at least commonly accepted beliefs, what are actually little more than unsubstantiated opinions or subjective impressions; several examples of infringement of this principle could be selected from the article quoted.

\section{American Association for the Advancement of Science : Meeting in Boston \\ THE one hundred and twentieth meeting of the American Association for the Advancement of Science will be held in Boston, Mass., during December 26-31, under the presidency of Dr. E. U. Condon, director of research, Corning Glass Works,}

